\title{
ASPEK DIPLOMASI, STRATEGI PERTAHANAN SEMESTA, DAN IRREGULAR WARFARE DALAM PENANGANAN GERAKAN DISINTEGRASI DI INDONESIA
}

\author{
Rizqa Noor Abdi, Joni Wijayanto \\ Universitas Pertahanan, Bogor, Indonesia \\ Email: rizqanoorabdi@gmail.com
}

\begin{abstract}
The aspects of diplomacy, total defense strategy, and irregular warfare are important aspects which, if combined correctly, will be effective in the strategy of winning the war, including fighting quelling uprisings that threaten the disintegration of the Unitary State of the Republic of Indonesia (Negara Kesatuan Republik Indonesia/NKRI). This paper presents a comparison of the application of the above aspects in three cases of rebellion in Indonesia, namely Darul Islam/ Tentara Islam Indonesia (DI/TII) in West Java, the Fretilin group in East Timor, and the Free Aceh Movement (Gerakan Aceb Merdeka/GAM) in Aceh. Descriptive comparisons refer to the use of library materials to describe the common thread of differences and similarities of the three movements. As a result, exposure to differences and similarities from the application of aspects of diplomacy, total defense strategy, and irregular warfare in the three cases above. Even though the time constraints and understanding of descriptive analysis may have been a limitation in this paper, the comparative presentation presented can be subject to further study, especially regarding the case of war to quell the rebellion in Indonesia
\end{abstract}

Keyword: Diplomacy; total defense strategy; and irregular warfare; war of the rebellion; comparison analysis.

Abstrak. Aspek diplomasi, strategi pertahanan semesta, dan irregular warfare adalah aspek penting jika dikombinasikan secara tepat akan efektif dalam strategi memenangkan peperangan, termasuk perang meredam pemberontakan yang mengancam disintegrasi Negara Kesatuan Republik Indonesia (NKRI). Makalah ini memaparkan perbandingan penerapan ketika aspek di atas dalam tiga kasus pemberontakan di Indonesia, yaitu Darul Islam/Tentra Islam Indonesia (DI/TII) di Jawa Barat, kelompok Fretelin di Timor-Timur, dan Gerakan Aceh Merdeka (GAM) di Aceh. Perbandingan deskriptif mengacu kepada penggunaan bahan pustaka dilakukan untuk memaparkan benang merah perbedaan dan persamaan dari ketiganya. Hasilnya, paparan perbedaan dan persamaan dari penerapan aspek diplomasi, strategi pertahanan semesta, dan irreguler warfare dari ketiga kasus di atas. Meskipun dengan keterbatasan waktu dan pemahaman analisis deskriptif mungkin menjadi batasan dalam makalah ini, tetapi paparan perbandingan yang disampaikan dapat menjadi bahan kajian selanjutnya, khususnya menyangkut kasus perang meredam pemberontakan di Indonesia.

Kata Kunci: Diplomasi; strategi pertahanan semesta; irregular warfare; perang pemberontakan; analisis perbandingan.

Permalink/DOI: https://doi.org/10.15408/mimbar.v37i1.17827 


\section{Pendahuluan}

Sejalan dengan dinamika perkembangan jaman, ilmu, dan teknologi; definisi sebuah perang juga turut berubah. Saat ini, dalam konteks perang mempertahankan NKRI, perang tidak hanya terkait dengan penggunaan kekuatan militer (bard power) dalam bidang pertahanan dan keamanan (HANKAM), tetapi lebih menonjol pada bidang ideologi, politik, ekonomi, sosial, dan budaya (IPOLEKSOSBUD) yang mengarah ke penggunaan diplomasi, pertahanan semesta, dan perang tidak beraturan (irreguler warfare) yang cenderung bersifat soft power.

Meskipun perang saat ini mengambil bentuk yang terbatas dan melibatkan pelaku di balik layar serta korbanya tidak langsung terlihat kasat mata; tetapi ruang lingkupnya lebih sistematis dan berdampak luas. Misalnya, perang intelijen, siber, dan perang dagang.

Di sisi lain, Elisabeth menerangkan bahwa perang dalam arti sengketa tidak hanya melibatkan pelaku dalam kawasan nasional sebuah negara, tetapi juga pada lingkup internasional. Bentuk entitas ini tidak lagi sebatas sebuah negara, tetapi juga entitas non- negara. Misalnya, perusahaan dan atau lembaga non-pemerintah (Non-Government Organization/NGO) atau sering disebut sebagai Lembaga Swadaya Masyarakat (LSM). Entitas negara sebagai pelaku perang mulai kurang dominan sejak selesainya perang dingin dengan bubarnya Uni Soviet di awal dekade 1990-an. Hanya saja, tujuan dari perang itu sendiri yang sepertinya masih sama, yaitu bagaimana satu pihak dapat menguasai sebagian atau secara keseluruhan pihak lain secara fisik dan atau secara non fisik. Kemudian mengendalikannya sesuai keinginan dan kepentingan pihak yang menang dan menguasai.

Dalam konteks yang terbatas, seperti dipaparkan oleh Wattimena (2018) tentang perang terbatas dalam lingkup sebuah negara, sepanjang sejarah mempertahankan kemerdekaan NKRI sampai saat ini, NKRI sudah mencatat beberapa kali perang secara beruntun, mulai dari pemberontakan Partai Komunis Indonesia (PKI) di Madiun tahun 1948, DI/TII tahun 1948-1962 sampai Pemberontakan Fretelin di Timor Timur tahun 1974-1999 dan GAM tahun 1976-2005. Dan saat ini, upaya disintegrasi oleh Organisasi papua Merdeka (OPM) masih menjadi tantangan tersendiri dalam upaya mempertahankan kemerdekaan NKRI sebagai harga mati. Sepanjang usaha mempertahankan kemerdekaan NKRI tersebut, tiga aspek utama yang mempengaruhi keberhasilannya mempertahankan keutuhan NKRI adalah aspek diplomasi, strategi pertahanan semesta, dan aspek irregular walfare.

Tulisan ini mencoba menjawab pertanyaan bagaimana ketika aspek tersebut mempengaruhi keberhasilan perang mempertahankan kemerdekaan NKRI. Kajian deskriptif ini dilakukan menggunakan teori identitas sosial dari dengan mengacu kepada makalah tentang Globalisasi dan Perkembangan Taktik Penanggulangan Pemberontakan di Indonesia dari Kilcullen yang membahas keberhasilan penggunaan aspek diplomasi, strategi perang semesta, dan irregular warfare pada kasus pemberontakan DI/TII dan kegagalannya pada kasus pemberontakan Fretelin di Timor Timur. Selanjutnya, para penulis mencoba mengembangkannya dengan membuat komparasi terhadap kedua kasus di atas dengan menambahkan satu kasus penanggulangan pemberontakan GAM. Di akhir tulisan, sebuah refleksi belajar dari pengalaman diajukan khususnya terhadap kasus OPM di Papua sebagai bahan diskusi selanjutnya.

\section{Definisi Diplomasi, Strategi Pertahanan Semesta, Dan Irregular Warfare}

Winston S. Churchill mengungkapkan bahwa "Diplomasi adalah seni mengatakan "Pergilah ke neraka" secara halus sehingga mereka menanyakan arahnya.". Diplomasi dapat didefinisikan juga sebagai seni dan praktik negosiasi antara perwakilan sebuah negara. Biasanya mengacu pada perilaku hubungan internasional melalui perantaraan diplomat profesional sehubungan dengan berbagai topik permasalahan tertentu. Sedangkan strategi pertahanan semesta, meminjam istilah dalam Buku PokokPokok Pikiran Perang Semesta dapat didefinisikan sebagai upaya mempertahankan kemerdekaan dan 
keutuhan NKRI dengan lebih banyak memanfaatkan elemen-elemen nir-militer untuk mencapai kemenangan.

Tentu, dalam hal ini penggunaan unsur- unsur militer masih digunakan tetapi hanya sebagai pendukung saja. Sedangkan irregular warfare adalah peperangan tidak teratur, yang bentuknya berbeda tetapi peperangan, menggambarkan jenis-jenis kekerasan yang dilakukan oleh aktor-aktor sub-negara termasuk terorisme dan pemberontakan. Contoh bentuk peperangan dengan persebaran pasukan antar pihak yang berperang berimbang hanya dengan kemampuan militer yang terbatas dan tidak beraturan, seperti kurang pelatihan, senjata tua, atau peralatan seadanya.

\section{Aspek Diplomasi, Strategi Pertahanan Semesta, Dan Irregular Warfare Dalam Perang Terhadap Pemberontakan Di/Tii Jawa Barat}

Pemberontakan DI/TII muncul dari ketidaksepakatan tentang bentuk Negara Indonesia yang baru merdeka, antara negara sekuler dan negara Islam. Gerakan ini dipimpin oleh Sekarmaji Marijan Kartusuwiryo, dari Garut di Jawa Barat, seorang pemimpin yang berpengaruh dikalangan penduduk Jawa Barat yang dikenal Islami. Sebagai pemimpin nasionalis Islam, Kartosuwiryo merasa kecewa dengan para pemimpin nasionalis sekuler dan kemudian ingin mendirikan negara Islam di Indonesia. Perang penanggulangan pemberontakan ini berjalan hampir 14 tahun dan berhasil diredam oleh TNI dengan strategi perang kontra-gerilya yang dicetuskan oleh Abdul Haris Nasution, komandan divisi Siliwangi TNI di Barat Jawa selama Perang Kemerdekaan.

Aspek diplomasi dalam perang meredam pemberontakan ini dilakukan dengan melakukan dialog dan pendekatan wawasan kenegaraan kepada tokoh masyarakat, agama, dan penduduk di wilayah ini terkait konteks keterwakilan nilai dan moral agama Islam dalam sistem perundang- undangan NKRI, yaitu dalam dasar negara Pancasila dan UUD 1945. Tujuannya adalah untuk memperoleh dukungan terhadap upaya peredaman pemberontakan DI/TII. Aspek strategi pertahanan semesta adalah dalam bentuk strategi perang pagar betis dengan melibatkan tenaga cadangan dari penduduk di sekitar kantong markas pemberontak untuk melokalisir ruang gerak mereka. Disamping itu, penggunaan kekuatan militer untuk melemahkan kekuatan pemberontak dengan keberhasilannya menangkap pemimpin DI/TII di tahun 1962. Terakhir, penggunaan tenaga cadangan dari penduduk di sekitar daerah pemberontah dengan penggunaan peralatan dan pelatihan seadanya merupakan juga sebagai bentuk penggunaan aspek irreguler warfare dalam perang penanggulangan pemberontakan DI/TII ini.

Singkatnya, upaya penanggulangan pemberontakan DI/TII berhasil dilakukan dengan ditangkap dan dihukum matinya pemimpin gerakan ini di tahun 1962. Dengan struktur organisasi DI/TII yang hirarkis dan kuatnya sisi ketokohan kepemimpinannya, hukuman mati dari pemimpin gerakan pemberontakan dengan dukungan aspek diplomasi lokal pada akhirnya memperlihatkan keberhasilan upaya mempertahankan keutuhan NKRI saat itu.

\section{Aspek Diplomasi, Strategi Pertahanan Semesta, Dan Irregular Warfare Dalam Perang Terhadap Pemberontakan Fretelin Di Timor Timur}

Berbeda dengan sejarah pemberontakan DI/TII di Jawa Barat, sejarah disintegrasi Timor-Timur berawal dari lepasnya bagian jajahan Timor Portugis dari Portugis setelah Revolusi Bunga tahun 1974 dan bergabungnya negara bagian jajahan itu menjadi wilayah NKRI setelah Deklarasi Balibo tahun 1975 dan tidak setujunya integrasi dari salah satu partai beraliran Marxis, yaitu Fretelin. Sejak itu, kelompok ini melakukan upaya pemberontakan untuk memisahkan diri kembali dari NKRI sampai keputusan disintegrasi tahun 1999. 
Berbeda juga dengan kasus DI/TII, aspek diplomasi dalam kasus meredam pemberontakan Fretelin dilakukan oleh pemerintah tidak hanya diplomasi ke dalam kepada para tokoh dan masyarakat di Timor- Timur, tetapi juga secara internasional mengingat sejarah integrasi wilayah tersebut dari wilayah jajahan Portugis. Sedangkan aspek pertahanan semesta dilakukan, selain menggunakan kekekuatan militer dalam menumpas kelompok pemberontak, upaya pembangunan bidang IPOLEKSOSBUD juga menjadi salah satu strategi pertahanan dalam kasus ini. Sedangkan aspek irregular warfare dilakukan dengan operasi militer secara pagar betis dengan melibatkan kekuatan cadangan dari kelompok simpatisan integrasi. Bahkan berhasil ditangkapnya salah satu pemimpin pemberontak tahun 1978, tidak menyurutkan upaya pemberontakan ini. Akhirnya, opsi referendum diajukan oleh pemerintah dan hasilnya keputusan pemisahan diri wilayah ini dari NKRI tahun 1999.

Secara umum, penggunaan aspek diplomasi, pertahanan semesta, dan irreguler warfare sepertinya tidak berhasil dalam upaya penanggulangan pemberontakan Fretelin di Timor-Timur. Kuatnya pengaruh Portugal sebagai rival Indonesia dalam diplomasi internasional khususnya di Eropa menjadi faktor utama dalam aspek diplomasi di sini. Selain itu, kondisi alam, sosial budaya, agama, dan sejarah yang jelas dengan wilayah lain NKRI juga menjadi faktor penting yang mempengaruhi aspek pertahanan semesta di Timor-Timur. Terakhir, struktur organisasi kelompok Fretelin yang beraliran Marxis juga sedikit banyak berpengaruh dalam kegagalan irreguler warfare. Salah satunya adalah taktik penangkapan pemimpin pemberontak tidak menyurutkan upaya gerakan ini, karena memang struktur organisasinya yang tidak hirarkis. Berbeda dengan kasus penangkapan pemimpin DI/TII di Jawa Barat.

\section{Aspek Diplomasi, Strategi Pertahanan Semesta, Dan Irregular Warfare Dalam Perang Terhadap Pemberontakan GAM}

Secara umum, faktor yang melatar pemberontakan GAM adalah tidak tuntasnya peredaman pemberontakan DI/TII pimpinan Daud Beureueh (1953-1962) di Aceh yang kemudian dilanjutkan dengan GAM jilid kedua yang berlatar belakang rasa ketidakadilan diantara kelompok masyarakat Aceh terhadap pembangunan yang tersentralistik pada jaman orde baru. Disamping itu, perasaan terancamnya posisi mereka, baik ekonomi, politik, dan sosial budaya.

Berbeda dengan aspek pertahanan semesta dan irreguler warfare yang kurang efektif dalam mendukung upaya mempertahankan integrasi NKRI terkait kasus GAM Aceh, aspek diplomasi menjadi penentu keberhasilan upaya penanggulangan pemberontakan ini dengan ditanda-tanganinya Deklarasi Helsinki tahun 2005. Sebagai komparasi, kasus pemberontakan GAM Aceh dan DI/TII di Jawa Barat mempunyai kesamaan dari sisi permasalahan yang menjadi pemicu pemberontakan. Selain itu, kondisi sosial, budaya dan agama yang juga sama. Faktor-faktor ini menjadi penentu keberhasilan aspek diplomasi. Berbeda dengan, DI/TII di Jawa Barat, selain kondisi alam yang berbeda dengan topografi penduduk yang tidak merata, menjadi hambatan tersendiri bagi penggunaan aspek pertahanan semesta dengan penggunaan kekuatan militer di dalamnya

Singkatnya, pemahaman bidang IPOLEKSOSBUD dari wilayah pemeberontakan menjadi faktor penting bagi pemerintah dalam keberhasilan upaya diplomatis. Selain itu, disamping struktur organisasi dari GAM yang hirarkis menjadi faktor penentu keberhasilan diplomasi pemerintah dimana kesepakatan dengan pemimpin pemberontak akan berpengaruh ke tingkat bawah di tingkat pengikutnya. Hal ini berbeda jelas dengan kasus Fretelin di Timor-Timur.

\section{Penutup}

Merujuk kepada perbandingan keberhasilan dan kegagalan dari ketiga kasus penanggulangan pemberontakan DI/TII di Jawa Barat, kelompok Fretelin di Timor-Timur, dan GAM di Aceh dapat digunakan sebagai bahan pembelajaran dalam upaya penanggulangan pemberontakan OPM di Papua. Pelaksanaan aspek diplomasi, pertahanan semesta, dan irreguler warfare menjadi upaya kombinasi yang 
efektif dalam upaya perang penanggulangan pemberontakan dalam mempertahankan kemerdekaan dan keutuhan NKRI. Hanya saja, pemahaman yang tepat terkait bidang IPOLEKSOSBUDHANKAM yang sedang berjalan dan kondisi alam wilayah pemberontakan menjadi faktor penentu tingkat keberhasilan penerapan ketika aspek di atas, termasuk juga dalam upaya penumpasan OPM di Papua. Termasuk juga pemahaman dari karakteritik OPM.

Meskipun, situasi, kondisi, dan karakteristik setiap pemberontakan mungkin kelihatan berbeda; tetapi juga mungkin ada sisi persamaan yang bisa diambil pelajaran. Misalnya, pendekatan diplomasi dengan mempertimbangkan motivasi historis dari kasus, kondisi geopolitik, sosial, budaya, dan agama dari penduduk di wilayah Papua. Tentu, terobosan-terobosan khusus berdasarkan karakteristik unik setiap kasus layak dipertimbangkan mengingat kekhasan setiap kasus. Tetapi hal itu bisa dikembangkan melalui analisis kasus serupa sebelumnya. Penjelasan- penjelasan deskriptif dalam makalah ini hanya dilakukan berdasarkan kajian pustaka terkait, keterbatasan sumber daya studi termasuk waktu dan kemampuan analisis para penulis mungkin menjadi batasan yang perlu dipertimbangkan dalam kajian sejenis selanjutnya.

\section{Daftar Pustaka}

Barston, R. Modern Diplomacy Essex: Pearson Education Ltd, 2006.

Djelantik, Sukawarsini. Diplomasi Dalam Politik Global. Unpar Press, 2016.

Dwijayanto, R. A. "Sistem Militer Dalam Tentara Islam Indonesia (Tii) Di Jawa Barat Pada Masa Kartosuwiryo " Risalah 3(12) (2016): 1948-62.

Elisabeth, A. "Dimensi Internasional Kasus Papua." Jurnal Penelitian Politik 3(1) (2006): 43-65.

Hogg, M. A. Social Identity Theory. Stanford University Press, 2018.

Hudaya, Fadhil, Mestika Zed, and Etmi Hardi. "Tinjauan Historiografi Tentang Kekerasan Di Timor Timur (1976-1999) Dalam Sastra Indonesia: Saksi Mata."Adisusilo, Sutarjo. (2002). Nasionalisme, Demokrasi, Civil Society. Jumal Iman, Ilmu, Budaya, III, (9): 4. Barston, R. Modern Diplomacy Essex: Pearson Education Ltd, 2006.

Djelantik, Sukawarsini. Diplomasi Dalam Politik Global. Unpar Press, 2016.

Dwijayanto, R. A. "Sistem Militer Dalam Tentara Islam Indonesia (Tii) Di Jawa Barat Pada Masa Kartosuwiryo " Risalab 3(12) (2016): 1948-62.

Elisabeth, A. "Dimensi Internasional Kasus Papua." Jurnal Penelitian Politik 3(1) (2006): 43-65.

Hogg, M. A. Social Identity Theory. Stanford University Press, 2018.

Hudaya, Fadhil, Mestika Zed, and Etmi Hardi. "Tinjauan Historiografi Tentang Kekerasan Di Timor Timur (1976-1999) Dalam Sastra Indonesia: Saksi Mata."Galanggang Sejarah 1, no. 1 (2019): 118-40.

Ilmar, A. "Radikalisme Gerakan Berbasis Etnis: Kasus Organisasi Papua Merdeka." The Indonesian Journal of Public Administration (IJPA) 3(2) (2017): 72-87. Jayanti, K. Konflik Vertikal Antara Gerakan Aceh Merdeka Di Aceh Dengan Pemerintah Pusat Di Jakarta Tabun 1976-2005. Vol. 19(1): Buletin Al-Turas, 2013. 
Kilcullen, D. "Globalisation and the Development of Indonesian Counterinsurgency Tactics. Small Wars \& Insurgencies." 17(1) (2006): 44-64.

Kilcullen, David. "Globalisation and the Development of Indonesian Counterinsurgency Tactics." Small Wars \& Insurgencies 17, no. 1 (2006): 44-64.

Kiras, J. D. "Irregular Warfare: Terrorism and Insurgency. ." Understanding Modern Warfare 224 (2007): 186-207.

Mujiyati, N, K Kuswono, and S. Sunarjo. "United States During the Cold War 1945-1990." HISTORIA Jurnal Program Studi Pendidikan Sejarah 4(1) (2016): 39-54.

Nugroho, R. A., S. G. Prakoso, and S IP. "Strategi Angola Dalam Resolusi Konflik Perang Saudara " (2017): 1975-2002.

Poeze, H. A. Madiun 1948: Pki Bergerak.

Yayasan Pustaka Obor Indonesia, 2011.

Prabowo, J. S. "Pokok-Pokok Pemikiran Tentang Perang Semesta." (2009).

Wattimena, A. A. R. Bisakah Perang Dibindari? Sejarah, Anatomi Dan Kemungkinan Perang Di Abad 21. Vol. 43: The Ary Suta Center Series on Strategic Management, 2018.Anderson, Bennedict (2008). Imagined Communities (Komunitas-komunitas Terbayang). Penerjemah Omi Intan Naomi. Jakarta: Insist Press. 